\title{
Implemenntasi Metode Problem Solving Untuk Meningkatkan Motivasi dan Hasil Belajar Siswa Mata Pelajaran Bahasa Ingris di SMPN 3 Bolo Tahun Pelajaran 2019/2020
}

\author{
Dahlan \\ SMPN 3 Bolo \\ dahlan_smpn3bolo74@gmail.com
}

\begin{abstract}
Proses pembelajaran dengan metode problem solving merupakan proses pembelajaran diluar kelas yang biasanya bertujuan agar siswa memiliki hasil belajar yang lebih mantap dan dapat memotivasi belajar siswa karena melaksanakan latihan-latihan selama melaksanakan tugas, sehingga pengalaman siswa dalam mempelajari sesuatu dapat lebih terintegrasi. Penelitian ini bertujuan untuk mengetahui Implementasi metode problem solving terhadap peningkatan motivasi dan hasil belajar siswa di SMPN 3 Bolo Tahun pelajaran 2019/2020. Jenis ini adalah Penelitian Tindakan Kelas (PTK), Desain Penelitian Tindakan Kelas yang digunakan sesuai dengan metode PTK Arikunto. Setiap siklus meliputi perencanaan, tindakan, pengamatan, evaluasi serta refleksi. Subyek dalam penelitian ini adalah siswa SMPN 3 Bolo Tahun Pelajaran 2019/2020 sebanyak 24 orang. Instrumen yang digunakan dalam penelitian ini adalah soal tes dan lembar observasi motivasi belajar. Berdasarkan analisis data yang telah dilakukan maka disimpulkan bahwa: (1) Implementasi metode problem solving dapat meningkatkan motivasi belajar siswa dalam pembelajaran Bahasa Inggris di SMPN 3 Bolo Tahun pelajaran 2019/2020. (2) Implementasi metode problem solving dapat meningkatkan hasil belajar siswa dalam pembelajaran Bahasa Inggris di SMPN 3 Bolo Tahun pelajaran 2019/2020.
\end{abstract}

\section{Keywords: Metode Problem solving, Motivasi belajar, Hasil belajar}

\section{PENDAHULUAN}

Reformasi pendidikan tidak cukup hanya dengan perubahan dalam sektor kurikulum, baik struktur maupun prosedur perumusannya. Pembaharuan kurikulum akan lebih bermakna bila diikuti oleh perubahan praktik pembelajaran didalam maupun diluar kelas. Indikator pembaharuan kurikulum di tunjukkan dengan adanya perubahan pola kegiatan pembelajaran, pemilihan media pendidikan, penentuan pola penilaian yang menentukan hasil pendidikan (Majid, 2006).

Kurikulum yang seimbang ialah apabila kurikulum itu dapat di hayati oleh siswa dan mengarahkannya ketingkat perkembangan yang lebih dewasa, yakni terbentuknya pribadi yang terintegrasi. Hal ini hanya mungkin tercapai apabila kurikulum menyediakan lingkungan yang memungkinkan siswa dapat melakukan kegiatan belajar mengajar, memuaskan kebutuhannya, memberikan pengalaman yang kaya dan berbagai ragam (Hamalik, 2007).

Kegiatan interaksi belajar mengajar harus selalu ditingkatkan efektifitas dan efesiensinya. Dengan banyaknya kegiatan pendidikan di sekolah, dalam meningkatkan mutu dan frekuensi isi pelajaran, maka sangat menyita waktu siswa untuk melaksanakan kegiatan belajar mengajar tersebut. Untuk mengatasi keadaan tersebut guru perlu memberikan tugas-tugas di luar jam pelajaran. Sebab bila hanya menggunakan seluruh jam pelajaran yang ada untuk tiap mata pelajaran hal itu tidak akan mencukupi tuntutan luasnya pelajaran yang diharuskan, seperti yang tercantum dalam kurikulum. Dengan demikian perlu diberikan tugas-tugas, sebagai selingan untuk variasi teknik penyajian ataupun dapat berupa pekerjaan rumah. Tugas semacam itu dapat dikerjakan diluar jam pelajaran, di rumah maupun sebelum pulang sekolah (Roestiya, 2008).

Motivasi tidak hanya menjadikan siswa terlibat dalam kegiatan akademik, motivasi juga penting dalam menentukan seberapa jauh siswa akan belajar dari suatu kegiatan pembelajaran atau seberapa jauh menyerap 
informasi yang disajikan kepada mereka. Siswa yang termotivasi untuk belajar sesuatu akan menggunakan proses kognitif yang lebih tinggi dalam mempelajari materi itu, sehingga siswa itu akan menyerap dan mengendapan materi itu dengan lebih baik. Tugas penting guru adalah merencanakan bagaimana guru mendukung motivasi siswa (Nur, 2007).

Kondisi tersebut guru sebagai pengajar hendaknya senantiasa berupaya mengubah pandangan siswa yang menganggap bahwa mata pelajaran Bahasa Inggris itu sulit. Untuk itu perlu adanya perbaikan dalam kegiatan belajar mengajar. Guru harus merencanakan dan mempersiapkan segala sesuatu yang menunjang segala proses pembelajaran, mengubah strategi mengajar dan memilih metode yang sesuai agar dapat menimbulkan minat dan motivasi untuk belajar. Untuk mengatasi permasalahan diatas dan guna mencapai tujuan pendidikan secara maksimal, peran guru sangat penting dan di harapkan guru memiliki cara/metode mengajar yang baik dan mampu memilih metode pelajaran yang tepat dan sesuai dengan konsep-konsep mata pelajaran yang akan disampaikan. Dalam belajar bahasa inggris, secara umum pembentukan konsep merupakan produk eksperimental. Oleh karena itu pembentukan konsep Bahasa Inggris tidak begitu saja di bentuk melalui informasi atau penjelasan. Konsep tidak begitu saja di pindahkan begitu saja di pindahkan dari seseorang kepada orang lain .

Cara yang paling efektif untuk membentuk konsep bahasa inggris adalah melalui pemecahan masalah. Cara pembentukan konsep secara khusus di atas tertuang dalam kurikulum sekolah menengah yang mengutamakan pengajaran bahasa inggris harus di pilih metode yang dapat membangkitkan minat dan mengaktifkan siswa sehingga menimbulkan sikap yang mendukung terhadap proses belajar mengajar, seperti metode eksperimen, demonstrasi dan diskusi. Dengan metode ini diharapakan siswa menguasai konsep-konsep Bahasa Inggris dan saling keterkaitannya serta mampu menggunakan metode ilmiah untuk memecahkan masalah-masalah yang di hadapinya.

Dari latar belakang di atas maka peneliti mengangkat judul: Implementasi metode problem solving untuk meningkatkan motivasi dan hasil belajar siswa mata pelajaran Bahasa Inggris di SMPN 3 Bolo Tahun pelajaran 2019/2020.

\section{METODE}

\section{Jenis Penelitian}

Penelitian ini merupakan penelitian tindakan kelas (PTK). Rancangan penelitian tindakan kelas ini terdiri dari dua siklus. Dalam setiap siklus terdiri dari empat tahap yaitu perencanaan, pelaksanaan tindakan, observasi dan refleksi. Yang dapat dilihat pada gambar:

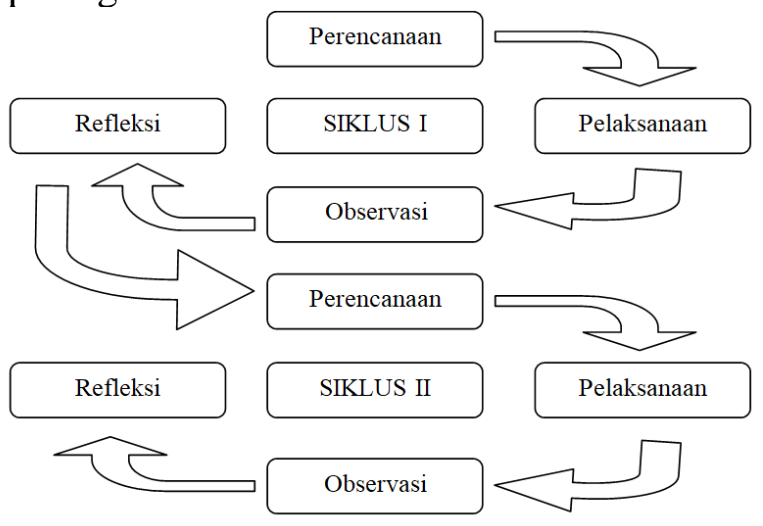

Gambar 1. Siklus Penelitian Tindakan Kelas (PTK) Arikunto dalam Azmin, (2019).

\section{Waktu dan Tempat Penelitian}

Penelitian ini dilaksanakan di SMPN 3 Bolo, pada Semester Ganjil Tahun Pelajaran 2019/2020.

\section{Subyek Penelitian}

Subyek dalam penelitian ini adalah siswa SMPN 3 Bolo Tahun Pelajaran 2019/2020 sebanyak 24 orang.

\section{Prosedur Penelitian}

Penelitian tindakan kelas ini direncanakan dalam dua siklus, setiap siklus dilaksanakan sesuai dengan skenario pembelajaran yang telah dibuat dan terdiri dari empat tahap kegiatan yaitu tahap perencanaan, tahap pelaksanaan tindakan, tahap observasi, dan tahap refleksi.

Adapun tahapan masing-masing siklus adalah sebagai berikut : 
Siklus I

a. Tahap perencanaan

Dalam tahap ini, hal-hal yang dilakukan oleh peneliti adalah :

1) Menyusun rencana pembelajaran

2) Membuat lembar observasi pembelajaran

3) Membuat lembar observasi

4) Mendesain alat evaluasi dan merencanakan analisis hasil tes.

b. Tahap pelaksanaan tindakan

Kegiatan yang dilakukan pada tahap ini adalah melaksanakan skenario pembelajaran yang telah direncanakan.

c. Tahap observasi

Kegiatan observasi dilakukan secara kontinyu setiap kali pembelajaran berlangsung dalam pelaksanaan tindakan dengan mengamati kegiatan guru dan aktivitas siswa.

d. Refleksi

Hasil yang diperoleh dari observasi, wawancara dan hasil evaluasi belajar siswa di kumpulkan serta dianalisis, sehingga dari hasil tersebut guru dapat merefleksi diri dengan melihat data observasi, yaitu: identifikasi kekurangan, analisis sebab kekurangan dan menentukan perbaikan pada siklus berikutnya.

\section{Siklus II}

Siklus II di lakukan apabila pelajaran pada siklus I belum berhasil mencapai ketuntasan atau hasil belajar dan proses mengajar belum sesuai dengan apa yang diinginkan, sedangkan langkah-langkah yang dilakukan dalam siklus II pada dasarnya sama dengan siklus I, hanya saja pada siklus II dilakukan perbaikan terhadap kekurangan pada siklus I.

\section{Instrumen Penelitian}

Instrumen Instrument yang digunakan dalam penelitian ini terdiri dari:

1. Soal Tes

Tes dalam penelitian ini digunakan untuk mengetahui hasil belajar siswa terhadap materi pelajaran. Tes yang digunakan dalam penelitian ini disusun dalam bentuk pilihan ganda sebanyak 10 butir soal yang di ambil dari buku paket Bahasa Inggris.

2. Lembar Observasi

Lembar Observasi dilakukan dengan tujuan untuk memperoleh gambaran langsung tentang proses pembelajaran Bahasa Inggris dengan menggunakan metode problem solving terhadap motivasi belajar siswa. Indikator yang digunakan dalam hal ini adalah (a). Mengkomunikasikan pemecahan masalah atas tugas yang telah diberikan oleh guru. (b). Kerjasama dalam kelompok (c). perhatian dan motivasi siswa dalam mengkuti kegiatan kelompok.

\section{Teknik Analisis Data}

Data yang diperoleh selanjutnya dianalisis dengan menggunakan analisis statistik sebagai berikut:

1. Analisis data observasi motivasi siswa

Untuk menjelaskan hasil motivasi belajar siswa menggunakan pendekatan kuantitatif. Pedoman kriteria penilaian motivasi belajar

\begin{tabular}{|c|l|c|}
\hline No & \multicolumn{1}{|c|}{ Interval } & Kategori \\
\hline 1 & $\mathrm{~A} \geq \mathrm{MI}+1,5 \mathrm{SDI}$ & $\begin{array}{c}\text { Sangat } \\
\text { Termotivasi }\end{array}$ \\
\hline 2 & $\begin{array}{l}\mathrm{MI}+0,5 \mathrm{SDI} \leq \mathrm{A}< \\
\mathrm{MI}+1,5 \mathrm{SDI}\end{array}$ & Termotivasi \\
\hline 3 & $\begin{array}{l}\mathrm{MI}-0,5 \mathrm{SDI} \leq \mathrm{A}< \\
\mathrm{MI}+0,5 \mathrm{SDI}\end{array}$ & $\begin{array}{c}\text { Cukup } \\
\text { Termotivasi }\end{array}$ \\
\hline 4 & $\begin{array}{l}\mathrm{MI}-1,5 \mathrm{SDI} \leq \mathrm{A}< \\
\mathrm{MI}-0,5 \mathrm{SDI}\end{array}$ & $\begin{array}{c}\text { Kurang } \\
\text { Termotivasi }\end{array}$ \\
\hline 5 & $\mathrm{~A}<\mathrm{MI}-1,5 \mathrm{SDI}$ & $\begin{array}{c}\text { Sangat Kurang } \\
\text { Termotivasi }\end{array}$ \\
\hline
\end{tabular}
rumus :

Kategori motvasi ditentukan dengan

$$
\begin{array}{ll}
\mathrm{MI} & =\frac{(\text { skormaksimum }+ \text { skorminimum })}{2} \\
\mathrm{SDI} & =\frac{1}{3} \mathrm{x} \text { MI }
\end{array}
$$

2. Ketuntasan individu

Ketuntasan individual atau ketuntasan per siswa ditentukan dengan rumus:

$$
\mathrm{K}=\frac{T}{T t} \times 100 \%
$$

Keterangan :

$$
\begin{aligned}
& \mathrm{K}=\text { Ketuntasan belajar per siswa } \\
& \mathrm{T}=\text { Skor yang dicapai siswa } \\
& \mathrm{Tt}=\text { Jumlah skor maksimal }
\end{aligned}
$$


Ketuntasan individual atau ketuntasan persiswa menurut standar ketuntasan belajar berdasarkan kurikulum tingkat satuan pendidikan berisi tentang kriteria dan mekanisme penetapan ketuntasan minimal mata pelajaran Bahasa Inggris yang ditetapan oleh sekolah SMPN 3 Bolo. Setiap siswa dalam proses belajar mengajar dinyatakan tuntas secara individu apabila memperoleh nilai $\geq 75$.

\section{Ketuntasan Klasikal}

Ketuntasan hasil belajar secara klasikal minimal $85 \%$ dari jumlah siswa yang memperoleh $\geq 75$. Dengan rumus ketuntasan belajar klasikal adalah :

$$
\mathrm{KK}=\frac{x}{z} \mathrm{X} 100 \% \text {. }
$$

Dimana :

$$
\begin{array}{ll}
\mathrm{KK} & =\text { Ketuntasan Klasikal } \\
\mathrm{X} & =\text { Jumlah murid yang memperoleh } \\
& \text { nilai } \geq 75 \\
\mathrm{Z} & =\text { Jumlah seluruh murid }
\end{array}
$$

\section{HASIL DAN PEMBAHASAN Hasil Penelitian}

Data kuantitatif yang diperoleh dari hasil evaluasi akan memberikan jawaban mengenai berhasil atau tidaknya proses pembelajaran dengan Implementasi pembelajaran problem solving untuk meningkatkan motivasi dan hasil belajar siswa di SMPN 3 Bolo yang diukur dengan ketuntasan belajar siswa secara klasikal. Data kuantitatif diperoleh dari hasil observasi yang memberikan gambaran tentang siswa terhadap proses belajar mengajar. Pada hasil penelitian akan diurai hal-hal sebagai berikut:

\section{Hasil Siklus I}

\section{a) Perencanaan}

Pada tahap perencanaan dilakukan kegiatan mempersiapkan rencana pelaksanaan pembelajaran, menyiapkan lembar observasi untuk mencatat aktivitas siswa dalam pembelajaran, lembar kerja siswa, dan menyiapkan soal evaluasi untuk mengetahui ketuntasan belajar siswa. Guru juga mengupayakan agar kondisi kelas kondusif sehingga proses pembelajaran dapat berjalan dengan baik, lancar, dan baik sesuai dengan rencana pelaksanaan pembelajaran.

\section{b) Pelaksanaan Tindakan}

Pelaksanaan tindakan pada siklus I dilakukan sesuai dengan skenario yang telah dibuat yaitu sebelum memulai pembelajaran guru terlebih dahulu memberikan apersepsi dan motivasi serta menyampaikan tujuan pembelajaran, hal ini ditujukan agar siswa lebih semangat serta termotivasi untuk mengikuti pelaksanaan pembelajaran.

Setelah selesai memberikan apersepsi dan motivasi serta menyampaikan tujuan pembelajaran, guru menyampaikan materi pembelajaran serta memberikan tugas kepada siswa secara berkelompok, setelah tugas diselesaikan dan dikumpulkan guru memanggil siswa tiap-tiap kelompoknya masing-masing. Setelah itu guru melakukan bimbingan kepada masing-masing siswa terutama kepada siswa yang kurang mampu, disamping itu guru selalu mendampingi siswa selama proses pembelajaran agar permasalahan-permasalahan yang dihadapi oleh siswa dapat diketahui dan menjelaskan permasalahan yang dihadapi oleh siswa tersebut. Guru bersama siswa menyimpulkan hasil pembelajaran. Pada akhir pertemuan siklus I diberikan tes evaluasi berupa tes tertulis.

a) Data hasil belajar siswa

Evaluasi siklus I dilaksanakan dengan alokasi waktu 2 X 45 menit. Data tentang ketuntasan belajar siswa pada siklus I dapat dilihat pada pada tabel 1 berikut:

Tabel 1. Data hasil evaluasi siklus I

\begin{tabular}{|c|c|c|c|}
\hline $\begin{array}{c}\text { Jumlah } \\
\text { Siswa }\end{array}$ & $\begin{array}{c}\text { Nilai } \\
\text { Rata- } \\
\text { rata }\end{array}$ & $\begin{array}{c}\text { Jumlah } \\
\text { Siswa Yang } \\
\text { Tuntas }\end{array}$ & $\begin{array}{c}\text { Presentase } \\
\text { Ketuntasan }\end{array}$ \\
\hline 24 & 66,67 & 13 & $54,67 \%$ \\
\hline
\end{tabular}

Dari tabel diatas dapat dilihat nilai ratarata kelas adalah 66,67. Dari 24 siswa yang mengikuti tes evaluasi terdapat 13 siswa yang tuntas sehingga ketuntasan belajar pada siklus I adalah 54,67\%. Jadi pelaksanaan pada siklus I belum mencapai ketuntasan belajar secara klasikal, dengan demikian perlu diadakan perbaikan pada siklus berikutnya. 
b) Data hasil observasi

Pada siklus I terlihat bahwa siswa belum siap menerima pelajaran dan melaksanakan pembelajaran dengan menggunakan metode problem solving secara berkelompok tidak berjalan sesuai dengan yang diharapkan, hal ini terlihat dari antusiasme siswa dalam mengikuti kegiatan pembelajaran masih kurang. Hal ini disebabkan karena guru sebelumnya tidak mensosialisasikan metode pembelajaran yang dBahasa Inggriskai, sehingga siswa tidak begitu antusias dalam mengikuti pelajaran.

Data lengkap tentang kegiatan siswa selama proses pembelajaran dengan Implementasi pembelajaran problem solving untuk meningkatkan motivasi dan hasil belajar siswa. Data ringkas tentang motivasi belajar siswa siklus I dapat dilihat pada tabel 2 .

Tabel 2. Data motivasi belajar siswa siklus I

\begin{tabular}{|c|c|c|l|l|l|}
\hline $\begin{array}{l}\text { Jumlah } \\
\text { siswa }\end{array}$ & $\begin{array}{l}\text { Sangat } \\
\text { termotivasi }\end{array}$ & Termotivasi & $\begin{array}{l}\text { Cukup } \\
\text { termotivasi }\end{array}$ & $\begin{array}{l}\text { Kurang } \\
\text { termotivasi }\end{array}$ & $\begin{array}{l}\text { Sangat } \\
\text { Kurang } \\
\text { termotivasi }\end{array}$ \\
\hline 24 & - & 7 & - & 17 & - \\
\hline
\end{tabular}

Dari tabel diatas motivasi belajar siswa makin kurang baik dengan jumlah dengan jumlah siswa yang termotivasi 7 .

c) Refleksi

Berdasarkan hasil evaluasi dan observasi pada siklus I, guru perlu membimbing siswa agar lebih aktif lagi dalam pembelajaran dan bisa menyimpulkan sendiri materi pembelajaran.Selain itu juga guru dituntut untuk bisa membangkitkan minat dan motivasi siswa agar pembelajaran menjadi lebih bermakna.

Memperhatikan permasalahan diatas, maka perbaikan untuk guru yang akan dilaksanakan pada siklus II adalah:

1. Guru hendaknya memberikan apersepsi menyampaikan tujuan pembelajaran dengan jelas agar dapat dBahasa Inggrishami oleh siswa.

2. Guru lebih meningkatkan motivasi kepada siswa untuk selalu aktif belajar dengan mengajukan beberapa pertanyaan dan meminta pendapat siswa yang kurang aktif sebagai rangsangan.

3. Guru membimbing atau melatih siswa untuk berani mengemukakan pendapat dan tidak malu bertanya pada guru atau temantemannya, serta memberikan penghargaan kepada siswa yang aktif dalam pembelajaran dengan memberikan senyuman, pujian, hadian dan sebagainya.

4. Guru perlu menjelaskan tugas-tugas yang diberikan kepada siswa hingga dapat dBahasa Inggrishami oleh siswa dan dapat diselesaikan dengan baik.

5. Guru perlu memberikan motivasi dalam meningkatkan semangat dan minat belajar siswa baik pada awal pembelajaran maupun saat pembelajaran berlangsung, sehingga lingkungan belajar yang efektif dan konduktif dapat tercipta.

\section{Hasil Siklus II}

1) Pelaksanaan

Prosedur pelaksanaan penelitian pada siklus II sama dengan siklus I.

a) Data ketuntasan belajar siswa

Setelah mengeroksi hasil evaluasi siklus II ini ternyata menunjukan bahwa hasil belajar siswa meningkat dan mendapat nilai cukup baik, dilihat dari banyaknya siswa yang tuntas dengan perolehan rata-rata kelas yaitu 83,33 dan ketuntasan secara klasikal sebesar 91,67\% ketuntasan klasikal dapat dilihat padatabel. 3 .

Tabel 3. Data hasil evaluasi siklus II

\begin{tabular}{|c|c|c|c|}
\hline $\begin{array}{c}\text { Jumlah } \\
\text { Siswa }\end{array}$ & $\begin{array}{c}\text { Nilai } \\
\text { Rata-rata }\end{array}$ & $\begin{array}{c}\text { Jumlah Siswa } \\
\text { Yang Tuntas }\end{array}$ & $\begin{array}{c}\text { Persentase } \\
\text { Ketuntasan }\end{array}$ \\
\hline 24 & 83,33 & 22 & $91,67 \%$ \\
\hline
\end{tabular}

b) Data hasil observasi

Siklus II terlihat bahwa siswa sudah siap menerima pembelajaran dengan menggunakan metode problem solving secara berkelompok dibandingkan tahap sebelumnya, ini terlihat dengan adanya antusias siswa saat mengajukan pertanyaan maupun menjawab pertanyaan, begitu juga dengan kemampuan siswa dalam menyelesaikan tugas yang diberikan oleh guru sudah baik.

Data lengkap tentang kegiatan guru dan siswa selama proses pembelajaran dengan Implementasi pembelajaran problem solving untuk meningkatkan motivasi dan hasil belajar siswa. Data ringkas tentang motivasi belajar siswa pada siklus II dapat dilihat pada tabel 4. 
Tabel 4. Data motivasi belajar siswa pada siklus II

\begin{tabular}{|c|c|c|c|c|c|}
\hline $\begin{array}{c}\text { Jumlah } \\
\text { siswa }\end{array}$ & $\begin{array}{c}\text { Sangat } \\
\text { termotivasi }\end{array}$ & Termotivasi & $\begin{array}{c}\text { Cukup } \\
\text { termotivasi }\end{array}$ & $\begin{array}{c}\text { Kurang } \\
\text { termotivasi }\end{array}$ & $\begin{array}{c}\text { Sangat } \\
\text { Kurang } \\
\text { termotivasi }\end{array}$ \\
\hline 24 & - & 16 & 2 & 6 & - \\
\hline
\end{tabular}

Dari data diatas terlihat bahwa motivasi belajar siswa sudah sangat baik dengan jumlah siswa termotivasi 16 . Hal ini menunjukan pelaksanaan pada siklus II sudah baik meskipun masih ada diskriptor yang belum nampak.

c) Refleksi

Dilihat dari hasil yang diperoleh pada siklus II telah tercapai hasil yang diharapkan walaupun demikian halnya masih ada siswa yang belum mampu mencapai target yang telah ditentukan, oleh sebab itu masih ada halhal yang perlu diperbaiki pada siklus berikutnya ataupun peneliti yang akan datang. Adapun kendala-kendala yang terdapat pada siklus II adalah sebagai berikut:

1. Pengaturan waktu yang belum sepenuhnya terlaksana.

2. Siswa masih kurang dalam mengkomunikasikan pendapatnya.

Akan tetapi sesuai dengan tujuan penelitian maka penelitian cukup dilaksanakan sampai siklus II

\section{Pembahasan}

\section{Motivasi belajar}

Motivasi merupakan suatu pendorong yang mengubah energi dalam diri seseorang kedalam bentuk suatu aktivitas nyata untuk mencapai tujuan tertentu. Menurut Sardiman (2008), motivasi adalah daya penggerak dari dalam dan di dalam subjek untuk melakukan aktivitas-aktivitas tertentu demi tercapainya suatu tujuan. Dalam proses pembelajaran disekolah motivasi merupakan salah satu faktor yang dapat mempengaruhi hasil belajar siswa.

Berdasarkan hasil observasi yang dilakukan pada siklus I dan siklus II motivasi belajar siswa mengalami peningkatan dari kategori baik maupun menjadi sangat baik. Motivasi belajar siswa mengalami peningkatan karena siswa telah memahami proses pembelajaran dengan menggunakan metode pemberian tugas secara berkelompok, sehingga siswa mampu bekerjasama dengan teman sekelompoknya, aktif dalam diskusi kelompok, mampu mengkomunikasikan pemecahan masalah-masalah yang diberikan oleh guru, tidak malu bertanya kepada guru ketika mengalami kesulitan dalam menyelesaikan tugas-tugas kelompok dan siswa mampu mempersentasikan hasil diskusinya didepan kelas serta memberikan tanggapan-tanggapan atas pertanyaan dari kelompok lain. Selain itu hal ini tidak lepas dari peranan guru yang selalu memberikan semangat, motivasi, pujian-pujian kepada siswa dan selalu membimbing siswa dalam proses belajar mengajar sehingga siswa termotivasi untuk belajar.

2. Hasil belajar

Berdasarkan analisis data, pemberian tindakan pada siklus I menunjukan bahwa nilai rata-rata kelas siswa sebesar 66,67 dan porsentase ketuntasan belajar siswa sebesar $54,67 \%$. Ini berarti hasil belajar siswa belum tercapai sesuai dengan konsep ketuntasan belajar klasikal. Hal ini disebabkan karena kurang siapnya siswa mengikuti proses pembelajaran. Sehingga beberapa siswa masih kurang mampu terutama dalam mengerjakan tugas-tugas yang diberikan. Implementasi pembelajaran problem solving pada siklus I masih belum sempurna, walaupun telah dilakukan sesuai dengan skenario yang telah dibuat. Setelah materi disampaikan dengan menerapkan pembelajaran problem solving kemudian diberikan tes, kemudian dikoreksi hasilnya ternyata masih banyak siswa yang belum tuntas. Ketuntasan belajar siswa dikatakan tuntas bila ketuntasan klasikal mencapai $85 \%$, pada pelaksanaan siklus I belum mencapai ketuntasan secara klasikal, dengan demikian perlu dilakukan perbaikan pada siklus berikutnya.

Pada siklus II dilakukan perbaikanperbaikan antara lain dengan memberikan motivasi kepada siswa bahwa setiap pokok bahasan yang disampaikan merupakan materimateri yang sangat penting, perbaikan selanjutnya adalah dengan Implementasi pembelajaran problem solving dan melengkapi kekurangan-kekurangan pada siklus I yang belum terlaksana secara maksimal. Setelah proses belajar mengajar 
selesai, diberikan evaluasi siklus II, diperoleh peningkatan dengan persentase ketuntasan klasikal mencapai $91,67 \%$ dengan rata-rata 83,33. Ini menunjukan bahwa ketuntasan klasikal telah tercapai yaitu apabila ketuntasan belajar siswa minimal $85 \%$ dari jumlah siswa yang memperoleh nilai $75 \mathrm{ke}$ atas.

Perbandingan yang diperoleh pada siklus I dan siklus II, nilai rata-rata kelas 66,67 pada siklus I meningkat menjadi 83,33 pada siklus II. Ketuntasan belajar siswa sebesar 54,65\% pad siklus I menjadi 91,67\% pada siklus II. Ketuntasan belajar tercapai sebab dalam proses pembelajaran dengan menerapkan metode problem solving telah terlaksana dengan baik, pengelolaan waktu telah terkontrol, guru selalu mengontrol dan membimbing siswa dalam menyelesaikan tugas dan tugas yang diberikan bersifat menarik, praktis, mendorong minat anak untuk mencari serta bersifat ilmiah. Implementasi metode problem solving dapat membuat pendidikan disekolah menjadi relevan dengan kehidupan siswa sehingga siswa mudah dalam proses pembelajaran. Selain itu penggunaan metode ini dapat membiasakan siswa menghadapi dan memecahkan masalah-masalah yang dihadapi serta merangsang kemampuan berfikir siswa secara kreatif dan menyeluruh dalam proses belajarnya.

Hal ini sesuai dengan pendapat Ahmadi dan Prasetia (2005), ada empat syarat menggunakan metode pemberian tugas yaitu tugas yang diberikan harus jelas, sehingga anak mengerti bentuk apa yang harus dikerjakan, waktu untuk mengerjakan tugas harus jelas, mengadakan control yang sistematis sehingga mendorong anak-anak bekerja dengan sungguh-sungguh dan tugas yang diberikan bersifat: menarik perhatian anak, mendorong anak untuk mencari, memahami dan menyampaikan, anak-anak mempunyai kemungkinan dapat menyelesaikan serta bersifat praktis dan ilmiah.

Proses pembelajaran dengan metode problem solving merupakan proses pembelajaran di luar kelas yang biasanya bertujuan agar siswa memiliki hasil belajar yang lebih mantap dan dapat memotivasi belajar siswa karena melaksanakan latihanlatihan selama melaksanakan tugas, sehingga pengalaman siswa dalam mempelajari sesuatu dapat lebih terintegrasi. Di samping itu untuk memperoleh pengetahuan melaksanakan tugas secara berkelompok dalam penyelesaian masalah akan memperluas dan memperkaya pengetahuan serta keterampilan siswa di sekolah melalui kegiatan-kegiatan diluar sekolah. Dengan kegiatan melaksanakan tugas tersebut siswa aktif belajar dan merasa terangsang atau termotivasi untuk meningkatkan belajar yang lebih baik, memupuk inisiatif dan bertanggung jawab serta dapat meningkatkan hasil belajar yang diinginkan dan dapat pula meningkatkan daya serap siswa dalam pembelajaran (Roestiyah, 2008).

\section{KESIMPULAN}

Berdasarkan hasil pembahasan diatas dapat disimpulkan bahwa:

1. Implementasi metode problem solving dapat meningkatkan motivasi belajar siswa dalam pembelajaran Bahasa Inggris di SMPN 3 Bolo Tahun pelajaran 2019/2020.

2. Implementasi metode problem solving dapat meningkatkan hasil belajar siswa dalam pembelajaran Bahasa Inggris di SMPN 3 Bolo Tahun pelajaran 2019/2020

\section{DAFTAR PUSTAKA}

Arikunto. S. 2010. Prosedur Penilitian Suatu Pendekatan Praktek. Jakarta:Renika Cipta.

Hamalik. 2007. Kurikulum dan Pembelajaran. Jakarta: Bumi Aksara.

Hamzah. 2008. Teori Motivasi dan Pengukuran. Jakarta: PT. Bumi Aksara.

Majid. 2006. Perencanaan Pembelajaran. Bandung: Remaja Rosdakarya.

Nur. 2007. Motivasi dan Pengukuran. Jakarta: PT. Rineka Cipta.

Roestiya. 2008. Strategi Belajar Mengajar. Jakarta: Rineka Cipta.

Sadirman. 2008. Interaksi dan Motivasi Belajar Mengajar. Jakarta: PT. Raja 
JUPE: Jurnal Pendidikan Mandala

http://ejournal.mandalanursa.org/index.php/JUPE/index
Vol. 5. No. 6 Desember 2020

p-ISSN: 2548-5555 e-ISSN: 2656-6745

Grafindo Persada. 